\title{
Concentration, production and turnover of viruses and dissolved DNA pools at Stn ALOHA, North Pacific Subtropical Gyre
}

\author{
Jennifer R. Brum* \\ School of Ocean and Earth Science and Technology, University of Hawaii, 1000 Pope Road, Honolulu, Hawaii 96822, USA
}

\begin{abstract}
The concentrations, production rates and turnover times of the components of the dissolved DNA (D-DNA) pool, including viruses, were investigated in a depth profile at Stn ALOHA in the North Pacific Subtropical Gyre. A recently developed centrifugal concentration method was used to quantify the 3 major components of the D-DNA pool: free or enzymatically-hydrolyzable D-DNA (ehD-DNA), D-DNA within viruses and uncharacterized bound D-DNA. The production rates of each of these components of the D-DNA pool were estimated using a dilution technique and the turnover times of each component were calculated. Concentrations of total D-DNA and ehD-DNA were approximately 1.2 and $0.6 \mathrm{ng} \mathrm{ml}^{-1}$, respectively, throughout the mixed layer (upper $100 \mathrm{~m}$ ), and decreased with increasing depth to 0.2 and $0.06 \mathrm{ng} \mathrm{ml}^{-1}$ at $500 \mathrm{~m}$, resulting in ehD-DNA constituting 27 to $51 \%$ of the total D-DNA pool. Concentrations of viruses ranged from 0.9 to $1.0 \times 10^{7} \mathrm{ml}^{-1}$ within the mixed layer and also decreased with increasing depth to $0.2 \times 10^{7} \mathrm{ml}^{-1}$ at $500 \mathrm{~m}$. The average mass of DNA per viral genome was estimated at each depth with viral genome fingerprinting, and ranged from 62.5 to 69.8 ag DNA per virus. Multiplying the concentration of viruses by the average mass of DNA per virus at each depth revealed the concentration of D-DNA within viruses, which ranged from 0.13 to $0.68 \mathrm{ng} \mathrm{ml}^{-1}$ and constituted 49 to $63 \%$ of the total D-DNA pool. There was no measurable concentration of uncharacterized bound D-DNA in the depth profile. The production rates of ehD-DNA and D-DNA within viruses ranged from 0.10 to 0.41 and 0.03 to $0.07 \mathrm{ng} \mathrm{ml}^{-1} \mathrm{~h}^{-1}$, respectively, within the mixed layer, but no production of D-DNA could be measured below the mixed layer. The calculated turnover times of ehD-DNA ranged from 0.97 to $6.2 \mathrm{~h}$ within the mixed layer and were 3 to 10 times shorter than the turnover times of D-DNA within viruses, which ranged from 9.6 to $24 \mathrm{~h}$. In addition, the amount of phosphorus that was calculated to be produced within the ehD-DNA was able to support the biologically available phosphorus (BAP) demand, based on previously reported measurements of BAP uptake at Stn ALOHA. Using the measured virus production rates, viruses were estimated to lyse 3.2 to $16.5 \%$ of the standing stock of bacteria at Stn ALOHA $\mathrm{h}^{-1}$, resulting in the release of ehD-DNA, which was estimated as 11 to $35 \%$ of the total ehD-DNA production. This research supports the hypothesis that individual components of the D-DNA pool are cycled at different rates and shows that viruses in open-ocean gyre systems may have large impacts on the microbial community there, including viral-induced mortality and subsequent release of cellular contents to the dissolved organic matter pool.
\end{abstract}

KEY WORDS: Dissolved DNA · Virus · Stn ALOHA · North Pacific Subtropical Gyre Resale or republication not permitted without written consent of the publisher

\section{INTRODUCTION}

Dissolved deoxyribonucleic acid (D-DNA) in aquatic environments is operationally defined as DNA that passes through a 0.2 or $0.22 \mu \mathrm{m}$ pore-size filter
(DeFlaun et al. 1986, Karl \& Bailiff 1989). The 3 major components of the D-DNA pool are free or enzymatically-hydrolyzable D-DNA (ehD-DNA; Siuda \& Chróst 2000), D-DNA within viruses, and an as-yet-uncharacterized form of bound D-DNA (Jiang \& Paul 1995). The 
percent of total D-DNA of all 3 components measured in the Gulf of Mexico was $50 \%$ free D-DNA, 8 to $15 \%$ D-DNA within viruses, and 35 to $42 \%$ unidentified bound D-DNA (Jiang \& Paul 1995). The percent of total D-DNA within viruses has been independently measured in many studies, usually resulting in an average of $<20 \%$ (Paul et al. 1991, Boehme et al. 1993, Weinbauer et al. 1993, 1995, Jiang \& Paul 1995).

D-DNA can be produced through protozoan grazing on bacteria (Turk et al. 1992, Ishii et al. 1998, Kawabata et al. 1998, Alonso et al. 2000), viral lysis (Weinbauer et al. 1993, Alonso et al. 2000), and potentially as exudates from growing bacteria (Paul et al. 1987, 1990). The D-DNA can then be taken up as intact polynucleotides by marine bacteria during transformation (DeFlaun et al. 1987, Frischer et al. 1990, 1994, Jeffrey et al. 1990, Paul et al. 1991), or used by bacteria as a nucleotide or nutrient source (Paul et al. 1988, Turk et al. 1992, Jørgensen et al. 1993, 1994, Jørgensen \& Jacobsen 1996, Siuda \& Güde 1996, Finkel \& Kolter 2001). Turnover times for the D-DNA pool, mediated by these production and uptake mechanisms, have been calculated to be 22.7 to $146 \mathrm{~d}$ in the Gulf of Mexico (Paul et al. 1987). However, estimates of bulk D-DNA pool dynamics are of limited ecological value because the individual D-DNA components are probably turning over at different rates due to their differing bioavailability and production and uptake mechanisms. For example, it has been hypothesized that ehD-DNA will be more labile and thus have faster turnover rates than bound D-DNA (including DNA within viruses), because the latter is resistant to enzymatic hydrolysis (Weinbauer et al. 1993, Siuda \& Chróst 2000). Therefore, measurements of production and turnover rates of the individual D-DNA pool components will result in more realistic conclusions regarding the roles of D-DNA in aquatic environments.

In addition to being part of the D-DNA pool, aquatic viruses have been shown to affect microbial loop dynamics, bloom termination, and host-community diversity (Wommack \& Colwell 2000). Viruses can affect microbial loop dynamics by infecting and lysing cells, resulting in cell death and the release of cell contents to the dissolved organic matter (DOM) pool. Virus-induced mortality of marine bacteria has been found to be similar in magnitude to that due to protozoan grazing (Fuhrman \& Noble 1995). This results in a large portion of microbial production in the oceans being cycled through the 'viral shunt', the transfer of cell contents to the DOM pool via viral lysis, instead of being transferred to higher trophic levels through grazing (Wilhelm \& Suttle 1999).

The recently developed centrifugal concentration method for quantification of D-DNA (Brum et al. 2004) was employed in a study of the composition and pro- duction of the D-DNA pool at Stn ALOHA in the North Pacific Subtropical Gyre. By using DNase treatment, virus enumeration and the measurement of viral DNA content in conjunction with the D-DNA quantification method, the 3 major components of D-DNA were quantified and the production rates and turnover times were measured for each component. This is the first comprehensive study of the dynamics of these individual pools, and the first study of D-DNA cycling in an open-ocean gyre system. The results are discussed in the context of the impact of viruses on the microbial community as well as cycling of D-DNA in a phosphorus-stressed (Björkman \& Karl 2003) marine ecosystem.

\section{MATERIALS AND METHODS}

Study location and sampling. All samples were collected from December 13 to 15, 2002, at Stn ALOHA $\left(22^{\circ} 45^{\prime} \mathrm{N}, 158^{\circ} \mathrm{W}\right)$ in the North Pacific Subtropical Gyre. This is an oligotrophic site that has an extensive $15 \mathrm{yr}$ set of biogeochemical data generated through the Hawaii Ocean Time-series (HOT) program. Seawater samples were collected with 121 SIO polyvinylchloride sampling bottles attached to a rosette equipped with a Seabird CTD. The concentrations of total D-DNA, ehD-DNA, uncharacterized bound DDNA, viruses and bacteria as well as the average amount of DNA per virus were measured at 5, 25, 45, $75,100,150,200$ and $500 \mathrm{~m}$. The production rates of total D-DNA, ehD-DNA, uncharacterized bound DDNA and viruses were measured at 5, 25, 45, 75, 150, and $200 \mathrm{~m}$ in this profile.

D-DNA concentrations. The concentrations of total D-DNA, ehD-DNA, D-DNA within viruses and uncharacterized bound D-DNA were each measured in 4 replicate samples per depth using the centrifugal concentration method exactly as previously described (Brum et al. 2004). By this method, tetrasodium ethylenediamine tetraacetic acid (tetrasodium EDTA) was added to seawater that was vacuum-filtered through $0.22 \mu \mathrm{m}$ pore-size PVDF (polyvinylidene difluoride) filters (Millipore) and stored at $4^{\circ} \mathrm{C}$ until analysis. Replicate samples were incubated for $30 \mathrm{~min}$ at $25^{\circ} \mathrm{C}$ with DNase (Sigma-Aldrich No. D5025) prior to addition of tetrasodium EDTA to stop DNase activity. Within $10 \mathrm{~d}$ of sample collection, a Centricon concentration unit (Millipore) was used to concentrate material greater than $10 \mathrm{kDa}$ from $15 \mathrm{ml}$ of sample. After the concentrate had been rinsed with Tris-EDTA buffer, DNA in the concentrate was quantified with SYBR Green I (Molecular Probes), a fluorescent doublestranded DNA stain, using a fluorescence spectrophotometer (Perkin-Elmer LS-5). ${ }^{35}$ S-labeled DNA was 
initially added to samples at tracer concentrations (final concentration $1300 \mathrm{dpm} \mathrm{ml}^{-1}$ ) to estimate recovery efficiency of each sample, and ${ }^{35} \mathrm{~S}$ radioactivity was measured with a liquid scintillation counter (Packard Tri-Carb 4640).

D-DNA within viruses was calculated by multiplying the concentration of viruses in the $0.22 \mu \mathrm{m}$ filtrate by the average mass of DNA per virus determined by viral genome fingerprinting (Steward et al. 2000, Steward 2001) at each depth sampled. The concentration of ehD-DNA was calculated by subtracting the concentration of D-DNA that was not hydrolyzed by DNase from the concentration of total D-DNA. The concentration of uncharacterized bound D-DNA was calculated by subtracting the concentration of D-DNA within viruses from the concentration of D-DNA that could not be hydrolyzed by DNase. The final error values for D-DNA component concentrations were determined by propagation of errors throughout all calculations (Skoog et al. 2000).

Viral and bacterial concentrations. Concentrations of viruses were measured using epifluorescence microscopy (Noble \& Fuhrman 1998). Samples were filtered through $0.22 \mu \mathrm{m}$ pore-size PVDF filters (Millipore), preserved with $0.02 \mu \mathrm{m}$ filtered glutaraldehyde (final concentration $2 \%$ ), and stored at $4{ }^{\circ} \mathrm{C}$. Within $5 \mathrm{~d}$ of sample collection, triplicate sample aliquots $(1 \mathrm{ml})$ were filtered onto $0.02 \mu \mathrm{m}$ pore-size Anodisc (Whatman) filters and stained with SYBR Green I; viruses were enumerated using a Nikon Eclipse E600 epifluorescence microscope. Bacterial concentrations were determined from duplicate seawater samples (2 ml) preserved with paraformaldehyde (final concentration $1 \%$ ) which were stored at $-80^{\circ} \mathrm{C}$ until analysis with a flow cytometer (Coulter EPICS 753; Monger \& Landry 1993). The pre-filtration of virus enumeration samples through a $0.22 \mu \mathrm{m}$ pore-size filter was required so that virus and D-DNA concentrations could be determined from the same sample. However, previous experiments had shown that all of the extracellular viruses at Stn ALOHA passed through this filter (Brum et al. 2004). Therefore, the quantified concentrations of viruses are reported and discussed as the total concentration of viruses.

Viral genome fingerprinting. Pulsed field gel electrophoresis (PFGE) was used to estimate the average DNA content per virus at each depth sampled (Steward et al. 2000, Steward 2001). After filtration through $0.22 \mu \mathrm{m}$ pore-size PVDF filters (Millipore), approximately 81 of seawater from each depth was concentrated using a vortex flow filtration system (Benchmark) equipped with a $30 \mathrm{kDa}$ filter (Membrex) followed by further concentration with $10 \mathrm{kDa}$ Centricon units (Millipore). PFGE was carried out with these samples using a CHEF-DR II pulsed field gel elec- trophoresis system (Bio-Rad) run for $18 \mathrm{~h}$ with pulses ramping from 1 to $15 \mathrm{~s}$. DNA molecular weight markers (Midrange I and lambda ladder; New England BioLabs) and mass standards (high DNA mass ladder; Invitrogen) were run on the same gel as samples. The gel was stained with SYBR Green I and the bands in each lane of the gel were analyzed with gel analysis software (Alpha Innotech). The average viral genome size for each depth was then calculated by dividing the sum of the abundance-weighted molecular weights for each band by the sum of the genome copy numbers for each band, in each lane. These average viral genome sizes were then used to calculate the average mass of DNA per viral genome assuming that the viral DNA was composed of equal amounts of adenine, thymine, guanine and cytosine.

Virus and D-DNA production. Production of viruses, total D-DNA, ehD-DNA, and uncharacterized bound D-DNA were measured using a dilution technique (Wilhelm et al. 2002). This method was originally described for virus production, but preliminary experiments had shown that D-DNA production could be measured by this technique as well, using the same principles. Seawater was collected from each depth the day before the incubation experiments, filtered through a $30 \mathrm{kDa}$ filter using a vortex flow filtration system (Benchmark), and stored at $4^{\circ} \mathrm{C}$ for use as a diluent. Preliminary experiments had shown that this filtration removes all viruses and over $90 \%$ of the D-DNA in seawater collected from Stn ALOHA. On the subsequent day, seawater samples (2 l) from the same depths were vacuum-filtered through $73 \mathrm{~mm}$ diameter, $0.22 \mu \mathrm{m}$ pore-size PVDF filters (Millipore). As each sample was filtering, a sterile transfer pipette was used to repeatedly direct jets of sample across the filter surface to help maintain particles in suspension. As the residual volume began to decrease to below $300 \mathrm{ml}, 30 \mathrm{kDa}$-filtered seawater collected the previous day from that depth was added to increase the volume to $500 \mathrm{ml}$. This addition of $30 \mathrm{kDa}$-filtered seawater was repeated 3 times in order to dilute viruses and D-DNA and allow them to pass through the filter while retaining bacteria. The retained seawater (approximate volume $200 \mathrm{ml}$ ) was then diluted with the $30 \mathrm{kDa}$ filtrate to a final volume of $2 \mathrm{l}$, resulting in a target dilution of viruses and D-DNA to approximately 10 to $20 \%$ of their initial concentrations. Of this prepared seawater, 3 aliquots of $500 \mathrm{ml}$ each were placed in $500 \mathrm{ml}$ acid-rinsed polycarbonate bottles (Nuclepore) and incubated in the dark at in situ temperatures in ship-board incubators. Subsamples were collected from each replicate every $3 \mathrm{~h}$ for $12 \mathrm{~h}$ to quantify the concentration of bacteria, viruses, total D-DNA, ehD-DNA, and uncharacterized bound D-DNA as previously described. 
Production rates of ehD-DNA and viruses for individual incubations were calculated as the slope of the initial linear increase of each measured parameter versus time using first-order linear regression analysis (Minitab). Because virus production is proportional to bacterial host abundance, the calculated production rates were then corrected for losses of bacteria during preparation of the incubation samples (Wilhelm et al. 2002). Again, virus concentrations were only determined from the $0.22 \mu \mathrm{m}$ filtrate, but this filtration has been shown not to exclude extracellular viruses at Stn ALOHA (Brum et al. 2004), so the measured production of viruses in the $0.22 \mu \mathrm{m}$ filtrate is also reported as the total production of viruses. Turnover times for each component of the D-DNA pool were calculated by dividing their concentrations by their production rates at each depth, assuming that their concentrations remained at steady state.

The production rates of ehD-DNA and viruses were then used to ascertain the potential for ehD-DNA as a phosphorus source, the rate of bacterial lysis by viruses, and the rate of D-DNA production as a result of viral lysis. The production rates of phosphorus within ehDDNA were calculated by multiplying the estimated ehDDNA production rates by the phosphorus content of DNA, which was assumed to be $9.7 \%$. Virus-induced bacterial mortality was estimated by dividing a range of burst sizes (15 to 28 viruses cell ${ }^{-1}$ ) determined for bacteria in an oligotrophic oceanic environment (Weinbauer \& Suttle 1999) by the estimated virus production rates to obtain the rate of bacterial lysis at Stn ALOHA. The rate of D-DNA production from this viral-induced lysis was calculated by multiplying the rate of bacterial lysis by a DNA content per bacterium of $1.6 \mathrm{fg}$, as determined at an offshore station by Fuhrman \& Azam (1982). These calculations assumed that all virus production is the result of bacterial lysis and that all the bacterial DNA is released to the D-DNA pool.

\section{RESULTS}

\section{D-DNA concentrations}

The concentration of total D-DNA was approximately $1.2 \mathrm{ng} \mathrm{ml}^{-1}$ throughout the mixed layer (upper $100 \mathrm{~m}$ ), declined significantly between 100 and $150 \mathrm{~m}$, and continued to decrease with increasing depth to $0.2 \mathrm{ng} \mathrm{ml}^{-1}$ at $500 \mathrm{~m}$ (Fig. 1). The concentration of ehDDNA had a depth profile similar to total D-DNA, but ranged from 0.06 to $0.66 \mathrm{ng} \mathrm{ml}^{-1}$ (Fig. 1), constituting 27 to $51 \%$ of the total D-DNA pool. Concentrations of viruses and bacteria were also highest in the mixed layer, ranging from 3.5 to $4.5 \times 10^{5} \mathrm{ml}^{-1}$ and 9.0 to $10.4 \times$ $10^{6} \mathrm{ml}^{-1}$, respectively, and declined sharply below $100 \mathrm{~m}$

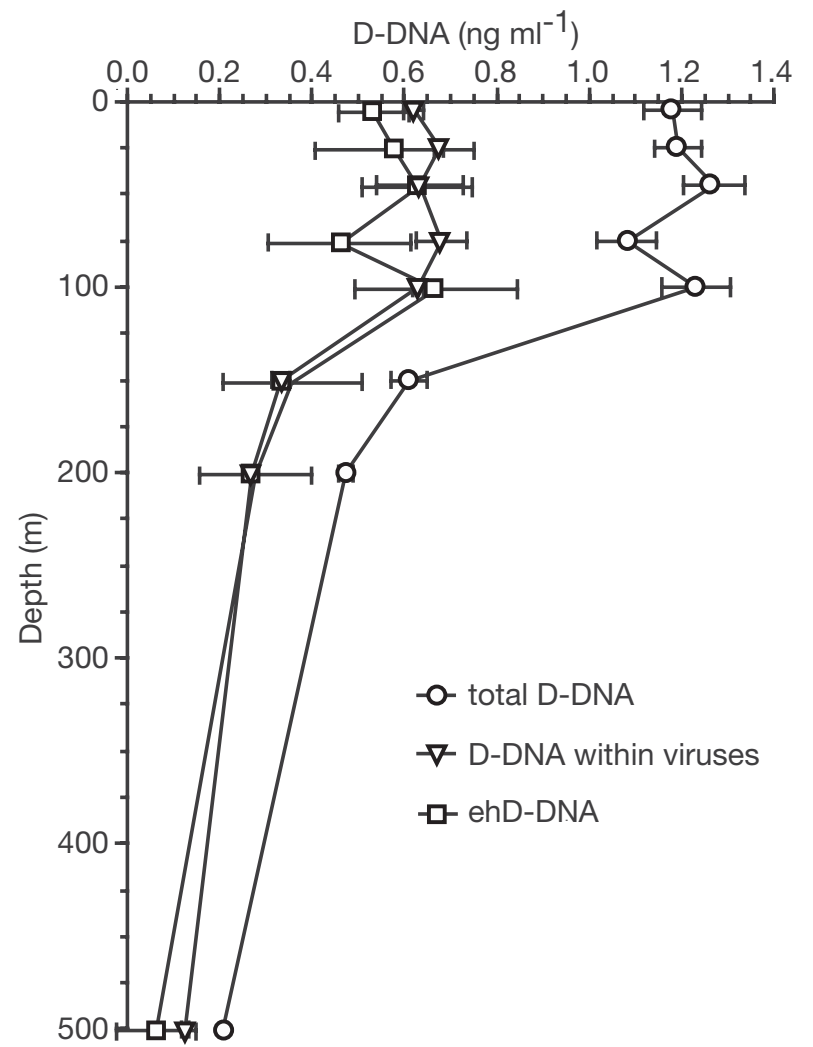

Fig. 1. Depth profiles of the concentrations of total D-DNA, ehD-DNA and D-DNA within viruses at Stn ALOHA. Error bars represent $\pm 1 \mathrm{SD}$ of the mean $(\mathrm{n}=4)$

to $0.7 \times 10^{5} \mathrm{ml}^{-1}$ and $2.0 \times 10^{6} \mathrm{ml}^{-1}$, respectively, at $500 \mathrm{~m}$ (Fig. 2). Average viral genome sizes ranged from 58 to $65 \mathrm{~kb}$ over all depths sampled and the average mass of DNA per viral genome calculated from the genome sizes ranged from 62.5 to 69.8 ag DNA virus ${ }^{-1}$ (Fig. 3). These calculated values were then used to convert the concentration of viruses at each depth to concentrations of DDNA within viruses, which ranged from 0.13 to $0.68 \mathrm{ng}$ $\mathrm{ml}^{-1}$ (Fig. 1), constituting 49 to $63 \%$ of the total D-DNA concentration. The concentration of D-DNA within viruses was not significantly different from the concentration of D-DNA that was not hydrolyzable by DNase (Student's $t$-tests, $\mathrm{p}>0.3$ for every depth) resulting in no measurable concentration of uncharacterized bound DDNA at any depth sampled. Therefore, at Stn ALOHA, there were 2 major components of the D-DNA pool: ehDDNA and D-DNA within viruses.

\section{ehD-DNA and virus production}

Preparations of seawater for incubation experiments diluted bacteria, viruses and total D-DNA, resulting in average initial concentrations of 20,7 and $16 \%$, respectively, relative to whole water samples. Because 


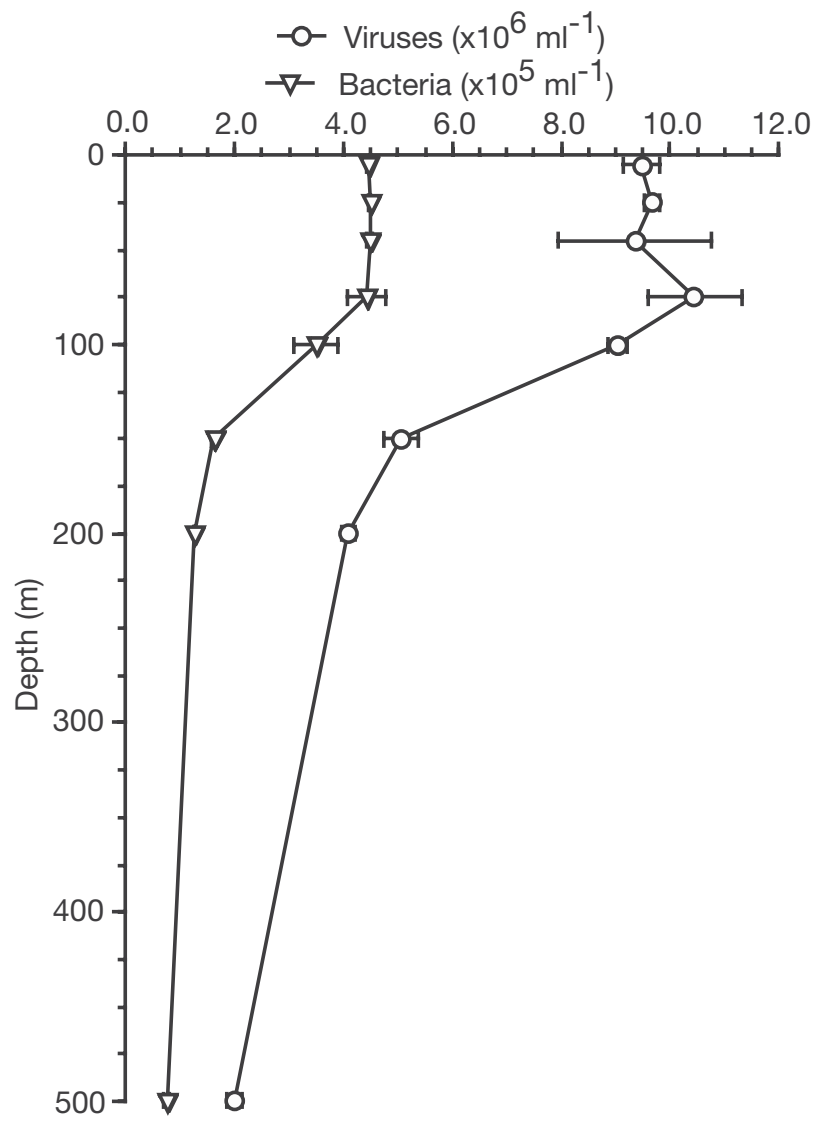

Fig. 2. Depth profiles of the concentrations of viruses and bacteria at Stn ALOHA. Error bars represent \pm 1 SD of the mean of triplicate samples for viruses and duplicate samples for bacteria

of low virus concentrations in the incubations, treatment of all samples with DNase resulted in D-DNA measurements that were not significantly different from blank values. Therefore, ehD-DNA concentrations were calculated by subtracting the D-DNA within viruses from total D-DNA for each time point sampled. Increases in ehD-DNA and virus concentrations were nearly linear for the first 3 to 4 time points (Fig. 4). The ehD-DNA concentration in the $75 \mathrm{~m}$ incubations had stopped increasing by the third time point (Fig. 4), so the production rate was calculated as the slope between the first 2 time points of the incubations. Because significant uptake of ehD-DNA may have already begun by the second time point, the calculated production rate is a minimum estimate of gross ehDDNA production at $75 \mathrm{~m}$. Because of only small fluctuations of ehD-DNA and virus concentrations, reliable production rates could not be determined in the 150 and $200 \mathrm{~m}$ incubations. Bacterial concentrations in the incubations did not change appreciably with time.

Virus production rates were similar for the 5, 25 and $45 \mathrm{~m}$ incubations $\left(4.0\right.$ to $\left.6.0 \times 10^{5} \mathrm{ml}^{-1} \mathrm{~h}^{-1}\right)$ and increased to approximately twice this rate in the $75 \mathrm{~m}$ incubations (Table 1). Using the calculated average DNA content per virion, these values translated into production rates of 0.03 to $0.07 \mathrm{ng} \mathrm{ml}^{-1} \mathrm{~h}^{-1}$ for D-DNA within viruses in the mixed layer (Table 1). Production of ehD-DNA was also similar at 5, 25, and $45 \mathrm{~m} \mathrm{(0.1} \mathrm{to}$ $0.15 \mathrm{ng} \mathrm{ml}^{-1} \mathrm{~h}^{-1}$ ) but was approximately 4 times higher at $75 \mathrm{~m}$ (Table 1). Turnover times of D-DNA within viruses ranged from 9.6 to $24 \mathrm{~h}$ and turnover times of ehD-DNA ranged from 0.97 to $6.2 \mathrm{~h}$ in the mixed layer (Table 1). Thus, production rates of D-DNA within viruses were 3 to 6 times lower and turnover times were 3 to 10 times longer than for ehD-DNA.

The production rates of phosphorus within ehDDNA were calculated to range from 7.5 to $30.8 \mathrm{nM} \mathrm{P}$ $\mathrm{d}^{-1}$ in the mixed layer (Table 2). These rates ranged from 78 to $422 \%$ of the rates of BAP uptake previously measured at the same depths at Station ALOHA (Björkman \& Karl 2003). The rate at which bacteria were lysed by viruses ranged from $1.4 \times 10^{4}$ bacteria $\mathrm{ml}^{-1} \mathrm{~h}^{-1}$ at $5 \mathrm{~m}$ to $7.3 \times 10^{4}$ bacteria $\mathrm{ml}^{-1} \mathrm{~h}^{-1}$ at $75 \mathrm{~m}$, resulting in 3.2 to $16.5 \%$ of the standing stock of bacteria lysed per hour in the mixed layer at Stn ALOHA (Table 3). This bacterial lysis was calculated to result in the production of 0.019 to $0.12 \mathrm{ng} \mathrm{DNA} \mathrm{ml}^{-1}$ $\mathrm{h}^{-1}$ as a result of bacterial DNA being released from the viral lysis of cells (Table 3 ). This calculated rate of D-DNA production from viral lysis of bacteria constituted 11 to $35 \%$ of the measured production of ehDDNA in the mixed layer at Stn ALOHA (Table 3).

\section{DISCUSSION}

\section{Components of D-DNA pool}

The total D-DNA depth profile in this study is in agreement with the D-DNA profile measured near this site using the CTAB (cetyltrimethylammonium bromide) method (Karl \& Bailiff 1989). The D-DNA pool was composed of an average of $48 \%$ ehD-DNA, which is similar to results for free D-DNA in the Gulf of Mexico (Jiang \& Paul 1995). However, the uncharacterized bound D-DNA described in the latter report was not detected at Stn ALOHA and may be a characteristic of more eutrophic areas.

The average percentage of total D-DNA within viruses at Stn ALOHA was $54.6 \%$ which is higher than the average percentages reported for other environments, which range from 3.7 \% in the Gulf of Mexico (Paul et al. 1991) to $18.3 \%$ in the Northern Adriatic Sea (Weinbauer et al. 1995). Previous studies have reported that DNA within viruses constitutes an average of $85 \%$ (Beebee 1991) and $90 \%$ (Maruyama et al. 1993) of the total DDNA pool, but the methods employed in those studies 


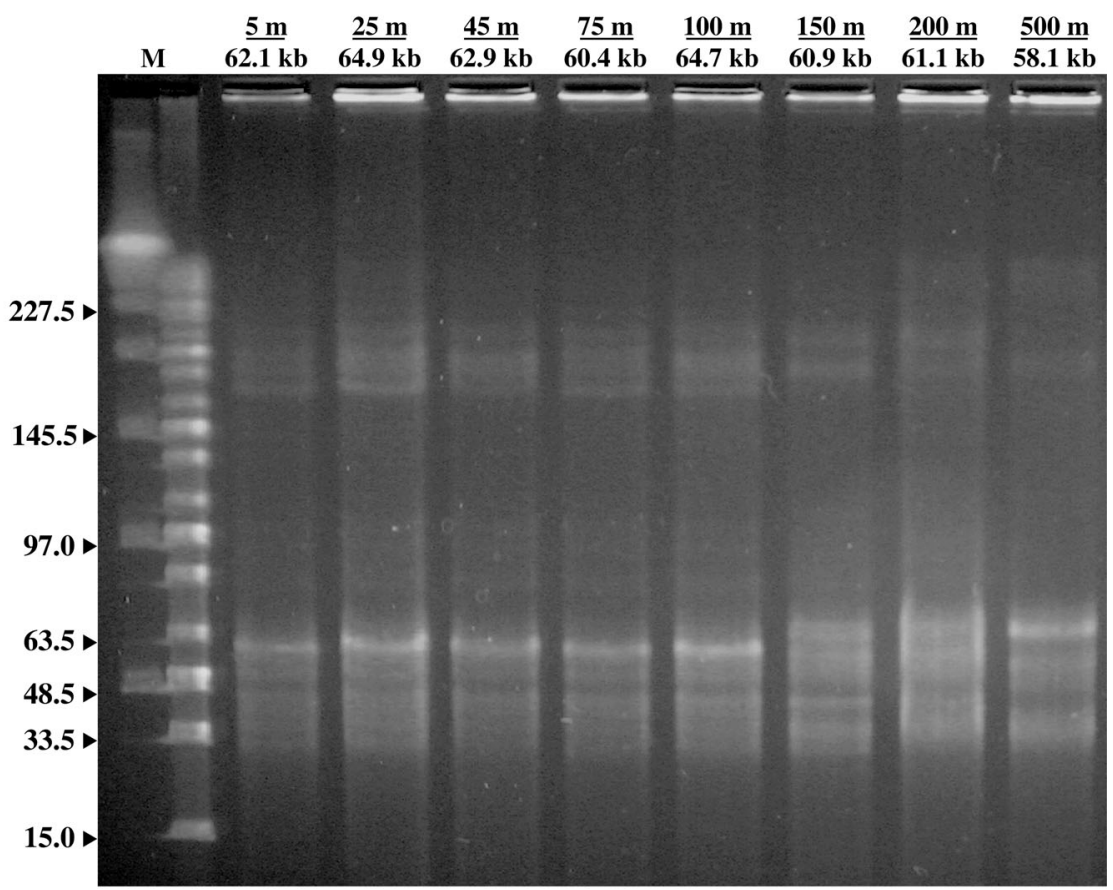

Fig. 3. Pulsed field gel electrophoresis (PFGE) banding patterns for viral concentrates from 8 depths at Stn ALOHA. The average length of DNA per viral genome is shown below the sampling depths at the top of the gel lanes. The marker lane (M) contains a 15 to $300 \mathrm{~kb}$ ladder and a lambda ladder. Sizes $(\mathrm{kb})$ of selected marker bands are indicated on the left

were later shown to overestimate the percentage of D-DNA within viruses by including high molecular weight D-DNA and uncharacterized bound D-DNA, respectively (Jiang \& Paul 1995). Seasonally high percentages of total D-DNA within viruses of up to $96.1 \%$ were found in the phosphorus-limited Northern Adriatic Sea (Weinbauer et al. 1993, 1995), but the remaining measurements in these studies (Table 4) suggest that D-DNA contained within viruses is not, overall, a large component of the D-DNA pool. However, none of the previous studies sampled open-ocean gyre systems, which comprise most of the world ocean. In this study, the faster turnover of ehD-DNA compared to D-DNA within viruses, coupled with the lack of uncharacterized bound D-DNA, may have served to increase the percentage of total D-DNA within viruses at Station ALOHA relative to other locations. It is not known whether the high percentage of D-DNA within viruses found in this study is typical of oligotrophic, open-ocean gyre environments.

\section{Production and turnover of ehD-DNA and viruses}

The production of ehD-DNA and viruses were relatively uniform throughout the mixed layer at Stn ALOHA, except at $75 \mathrm{~m}$ where ehD-DNA production rates were 4 times greater and virus production rates 2 times greater than at the other depths sampled in the mixed layer. There was no increase in the concentration of ehD-DNA or viruses at this depth, resulting in turnover times that were much shorter than those measured at other depths in the mixed layer. This suggests that there was greater uptake or degradation of ehDDNA and viruses at $75 \mathrm{~m}$ as well as higher production rates. The cause of faster cycling rates at $75 \mathrm{~m}$ is unknown, but could potentially be caused by greater bacterial activity or a large viral lysis event.

The production rates of ehD-DNA and viruses were undetectable below the mixed layer and coincided with the decrease in the concentration of bacteria, which are thought to be the major producers of viruses (Wommack \& Colwell 2000) and perhaps D-DNA (Paul et al. 1987, 1990). Nearly undetectable rates of virus production below $100 \mathrm{~m}$ were also reported for the Bering and Chukchi Seas, where it was also found that concentrations of bacteria declined below this depth (Steward et al. 1996). This undetectable production is the most likely cause of the sharp decrease in ehD-DNA and virus concentrations below the mixed layer at Stn ALOHA.

The production of ehD-DNA was 3 to 6 times faster than the production of D-DNA within viruses, resulting in turnover times of ehD-DNA that were 3 to 10 times shorter than turnover times of D-DNA within viruses. It seems logical that the 3 major components of the D-DNA pool described by Jiang \& Paul (1995) would turn over at different rates, based on their relative lability and different production and uptake mechanisms. Unless cells take up D-DNA during transformation, it must be hydrolyzed by cell-associated or extracellular enzymes before being transported into the cell (Paul et al. 1988). It is therefore reasonable that ehD-DNA will be turned over more rapidly than bound forms of D-DNA that are not readily hydrolyzed by DNase. In contrast, D-DNA within viruses will be turned over primarily as a function of the ability of viruses to infect their hosts and replicate. Therefore, as previously suggested (Weinbauer et al. 1993, Siuda \& Chróst 2000), measurements of the turnover of individual components of the D-DNA pool will more accurately reflect the ecological roles of D-DNA. This study supports these hypotheses by demonstrating that ehD-DNA turns over much faster than D-DNA within viruses at Stn ALOHA. 


\section{ehD-DNA as a phosphorus or nucleotide source}

It has been speculated that low D-DNA concentrations may result from increased utilization of D-DNA in phosphorus-limited systems (Weinbauer et al. 1993). Direct measurements of D-DNA production have been made in the Gulf of Mexico (Paul et al. 1987), but these measurements only included D-DNA produced by actively growing bacteria and were much lower than the production rates measured at Stn ALOHA, which include D-DNA produced from all sources. However, Paul et al. (1987) did find lower concentrations and shorter turnover times of the D-DNA pool at an oligotrophic offshore environment than at eutrophic coastal environments. Turnover times of ehD-DNA at Stn ALOHA were even shorter than those reported for the offshore station in the Gulf of Mexico. This suggests that there may be a relationship between lower D-DNA concentrations and shorter turnover times with increasingly oligotrophic conditions.

DNA is rich in phosphorus, with a molecular $\mathrm{C}: \mathrm{N}: \mathrm{P}$ ratio of approximately 10:4:1, and is the major information molecule of all living organisms. Considering its rapid turnover, ehD-DNA can potentially be a large source of nucleotides or phosphorus for microorganisms in the mixed layer at Stn ALOHA. Previous research suggests that D-DNA is taken up primarily by bacteria (Paul \& David 1989, Turk et al. 1992, Siuda \& Güde 1996, Siuda et al. 1998) and that the hydrolysis products of D-DNA are mostly salvaged into nucleic acids within the cell (Paul et al. 1988). It has also been found that orphophosphate is generated from 5'nucleotides by bacterial cell-surface $5^{\prime}$-nucleotidase (Ammerman \& Azam 1985) and that extracellular breakdown of plasmid DNA results in the release of phosphorus (Matsui et al. 2001), indicating that DDNA is part of a phosphorus regeneration mechanism. D-DNA uptake has also been linked to the phosphorus status of bacteria in the marine environment. D-DNA has been shown to be taken up more rapidly when added to phosphorus-limited samples than when added to nitrogen-limited (Turk et al. 1992) or phosphate-amended (Jørgensen \& Jacobsen 1996) samples. These studies suggest that in phosphoruslimited or phosphorus-stressed systems such as Stn ALOHA, D-DNA can be exploited as a source of phosphorus and/or as a source of nucleotides which require phosphorus for the cell to synthesize.

Over the last decade, there has been a decrease in the soluble reactive phosphorus (SRP) pool at Stn ALOHA (Karl et al. 2001a,b). As discussed by Björkman \& Karl (2003), this implies that microorganisms at Stn ALOHA must intensify recycling of phosphorus compounds or exploit other phosphorus sources. The measured production of ehD-DNA in the mixed layer at Stn ALOHA contains enough phosphorus to support
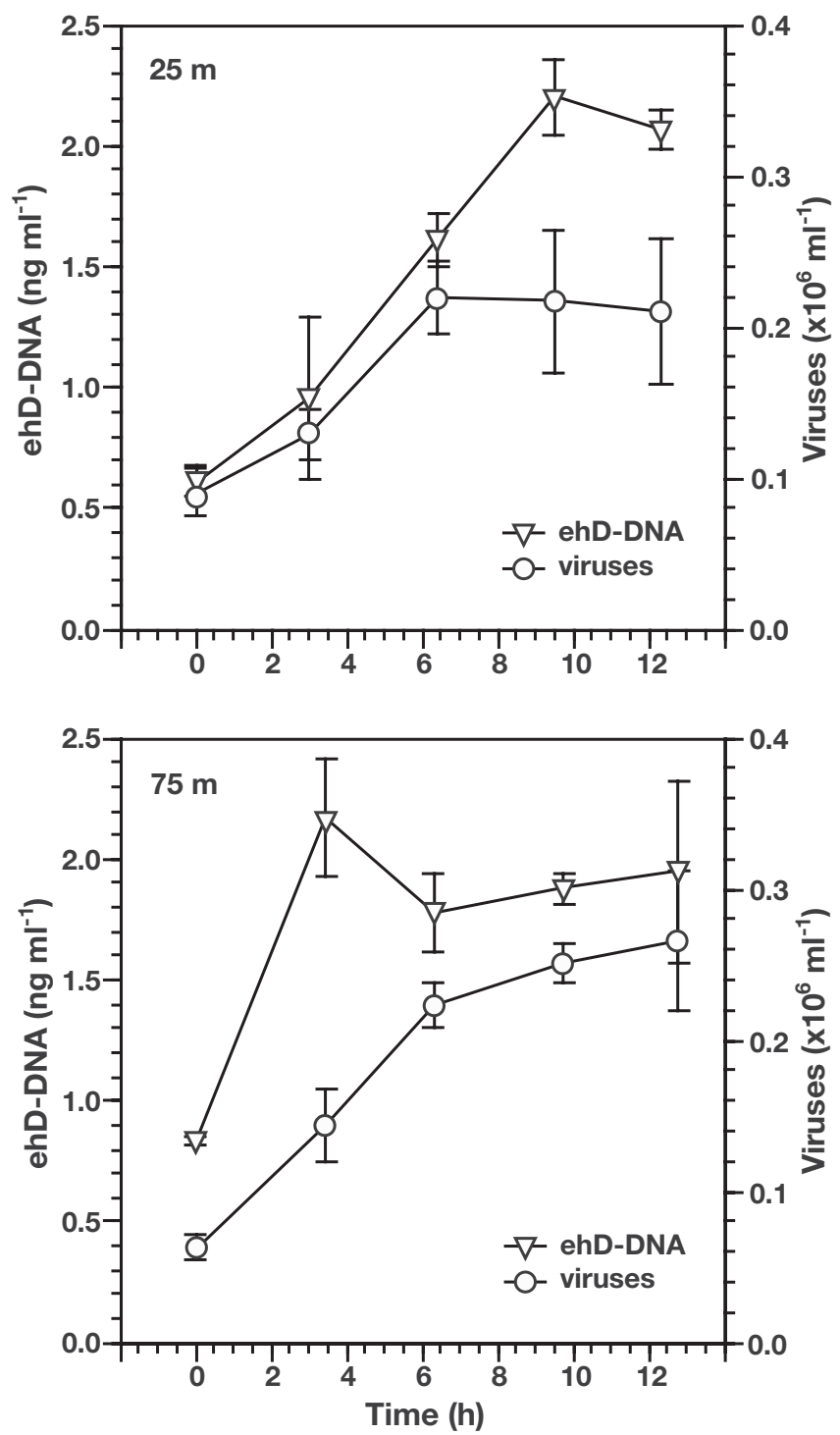

Fig. 4. Examples from 25 and $75 \mathrm{~m}$ of the change in concentrations of ehD-DNA and viruses over time in the incubations used to measure production rates. Error bars represent $\pm 1 \mathrm{SD}$ of the mean $(\mathrm{n}=3)$

the BAP demand previously measured there (Björkman \& Karl 2003). Thus, it is feasible that ehD-DNA could be a significant phosphorus and/or nucleotide source for the microbial community in the phosphorusstressed North Pacific Subtropical Gyre.

\section{Impact of viruses at Stn ALOHA}

The virus-mediated bacterial mortality at Stn ALOHA was estimated from virus production, assuming that bacteria were the only source of viruses at this station. This assumption is certainly not true, since viruses that infect phytoplankton have been 
Table 1. Estimated production rates and turnover times of viruses, D-DNA within viruses and ehD-DNA. Data are means $( \pm 1 \mathrm{SD})$ of triplicate samples. Data from 150 and $200 \mathrm{~m}$ not shown as production rates at these depths were below detection limit

\begin{tabular}{|c|c|c|c|c|c|}
\hline \multirow{2}{*}{$\begin{array}{l}\text { Depth } \\
\text { (m) }\end{array}$} & \multirow{2}{*}{$\begin{array}{c}\text { Viruses } \\
\text { Production } \\
\left(\times 10^{5} \mathrm{ml}^{-1} \mathrm{~h}^{-1}\right)\end{array}$} & \multicolumn{2}{|c|}{ D-DNA within viruses } & \multicolumn{2}{|c|}{ ehD-DNA } \\
\hline & & $\begin{array}{l}\text { Production } \\
\left(\mathrm{ng} \mathrm{ml}^{-1} \mathrm{~h}^{-1}\right)\end{array}$ & $\begin{array}{l}\text { Turnover } \\
\text { time (h) }\end{array}$ & $\begin{array}{l}\text { Production } \\
\left(\mathrm{ng} \mathrm{ml}^{-1} \mathrm{~h}^{-1}\right)\end{array}$ & $\begin{array}{l}\text { Turnover } \\
\text { time (h) }\end{array}$ \\
\hline 5 & $4.0( \pm 1.6)$ & $0.03( \pm 0.01)$ & $24( \pm 9.5)$ & $0.15( \pm 0.06)$ & $3.7( \pm 1.5)$ \\
\hline 25 & $6.0( \pm 1.1)$ & $0.04( \pm 0.01)$ & $16( \pm 3.0)$ & $0.13( \pm 0.02)$ & $4.0( \pm 0.8)$ \\
\hline 45 & $4.3( \pm 0.5)$ & $0.03( \pm 0.003)$ & $22( \pm 4.1)$ & $0.10( \pm 0.01)$ & $6.2( \pm 1.2)$ \\
\hline 75 & $11( \pm 1.1)$ & $0.07( \pm 0.007)$ & $9.6( \pm 1.2)$ & $0.41( \pm 0.12)$ & $0.97( \pm 0.34)$ \\
\hline
\end{tabular}

\section{Methodological considerations}

The estimates of ehD-DNA and virus production in this study relied on measuring the rates at which they were produced from bacteria recovered in the incubation samples, and multiplying these rates to reflect production from the entire bacterial population. Improvements in recovery of bacteria for these incubations will undoubtedly identified; but positive correlations between bacteria and virus concentrations have been reported in the North Pacific Subtropical Gyre (Culley \& Welschmeyer 2002), adding to the evidence that bacteria may be the major hosts of viruses (Wommack \& Colwell 2000). The percent of bacteria lysed in the mixed layer at Stn ALOHA was estimated to range from 3.2 to $16.5 \%$ of the standing stock of bacteria per hour. Because of the relatively slow growth of bacteria at Station ALOHA (Jones et al. 1996) the high percent of bacteria lysed at $75 \mathrm{~m}$ is almost certainly not sustainable, but it may be indicative of a large viral lysis event or a short-lived increase in bacterial activity fueled by nutrient input from below the mixed layer. A time series of virus production measurements at Stn ALOHA would improve accuracy in determining the impact of viruses at this site. However, it appears that viruses can exert considerable control over the bacterial population at Stn ALOHA.

As a result of viral lysis, the cell contents of the lysed bacteria are released to the dissolved pool, where they may be utilized by other organisms, particularly bacteria (Fuhrman 1992, 1999, Bratbak et al. 1994, Wilhelm \& Suttle 1999). The rate of DDNA production from viral-induced lysis of bacteria ranged from 11 to $35 \%$ of the ehD-DNA production, which is slightly lower than estimates indirectly inferred from the Northern Adriatic Sea (Weinbauer et al. 1995). Thus, the release of D-DNA through viral lysis of bacteria is a significant portion of ehD-DNA production at Stn ALOHA, but viral lysis is probably not the major mechanism of its production. The remaining ehD-DNA is most likely produced through grazing, exudation by growing bacteria, or autolysis of bacteria.
Table 2. Production of phosphorus within ehD-DNA compared to biologically available phosphorus (BAP) uptake measured previously (Björkman \& Karl 2003) in the mixed layer at Stn ALOHA. D-DNA is assumed to have $9.7 \%$ phosphorus content. Data are means $( \pm 1 \mathrm{SD}$ where applicable)

\begin{tabular}{|lcc|}
\hline $\begin{array}{c}\text { Depth } \\
(\mathrm{m})\end{array}$ & $\begin{array}{c}\text { ehD-DNA production } \\
\left(\mathrm{nM} \mathrm{P} \mathrm{d}^{-1}\right)\end{array}$ & $\begin{array}{c}\text { BAP uptake } \\
\left(\mathrm{nM} \mathrm{P} \mathrm{d}^{-1}\right)\end{array}$ \\
\hline 5 & $11.3( \pm 4.5)$ & 6.6 \\
25 & $9.8( \pm 1.5)$ & 8.8 \\
45 & $7.5( \pm 0.75)$ & 9.6 \\
75 & $30.8( \pm 9.0)$ & 7.3 \\
\hline
\end{tabular}

Table 3. Impact of viral lysis on mortality of bacteria and subsequent release of bacterial DNA to D-DNA pool. Data based on virus production, with burst size range for oligotrophic oceanic environments of 15 to 28 (Wainbauer \& Suttle 1999). D-DNA produced due to lysis based on DNA content of 1.6 fg DNA per bacterium for an offshore station (Fuhrman \& Azam 1982)

\begin{tabular}{|lcccc|}
\hline $\begin{array}{l}\text { Depth } \\
(\mathrm{m})\end{array}$ & \multicolumn{2}{c}{ Bacteria lysed } \\
& $\left(\times 10^{4} \mathrm{ml}^{-1} \mathrm{~h}^{-1}\right)$ & $\left(\% \mathrm{~h}^{-1}\right)$ & $\begin{array}{c}\text { D-DNA from viral lysis } \\
\left(\mathrm{ng} \mathrm{ml}^{-1} \mathrm{~h}^{-1}\right)\end{array}$ & $\begin{array}{c}\text { ehD-DNA } \\
\text { from viral lysis } \\
(\%)\end{array}$ \\
\hline 5 & $1.4-2.6$ & $3.2-5.9$ & $0.019-0.042$ & $11-26$ \\
25 & $2.1-4.0$ & $4.7-8.8$ & $0.034-0.063$ & $19-35$ \\
45 & $1.5-2.9$ & $3.4-6.4$ & $0.025-0.046$ & $18-34$ \\
75 & $3.9-7.3$ & $8.8-16.5$ & $0.062-0.12$ & $13-24$ \\
\hline
\end{tabular}

Table 4. Percentage of D-DNA within viruses in marine environments. Data are means $\pm \mathrm{SD}$; range of measurements is shown in parentheses where applicable, n: no. of samples

\begin{tabular}{|c|c|c|c|}
\hline Location & $\%$ & $\mathrm{n}$ & Source \\
\hline \multicolumn{4}{|l|}{ Gulf of Mexico } \\
\hline Coastal and offshore stations & $\begin{array}{l}3.7 \pm 3.8 \\
(0.9-12.3)\end{array}$ & 5 & Paul et al. (1991) \\
\hline Coastal and offshore stations & $4 \pm 5.8$ & 29 & Boehme et al. (1993) \\
\hline Coastal and offshore stations & $\begin{array}{l}12.9 \pm 5.8 \\
(6.6-21.8)\end{array}$ & 5 & Jiang \& Paul (1995) \\
\hline \multicolumn{4}{|l|}{ Northern Adriatic Sea } \\
\hline $\begin{array}{l}\text { Time-series of coastal and } \\
\text { offshore stations }\end{array}$ & $\begin{array}{c}17.1 \pm 19.6 \\
(0.7-88.3)\end{array}$ & 35 & Weinbauer et al. (1993) \\
\hline Time-series of coastal stations & $\begin{array}{l}18.3 \pm 26.2 \\
(0.1-96.1)\end{array}$ & 24 & Weinbauer et al. (1995) \\
\hline \multicolumn{4}{|l|}{ North Pacific Subtropical Gyre } \\
\hline Stn ALOHA & $\begin{array}{c}54.6 \pm 4.9 \\
(49.4-62.8)\end{array}$ & 8 & This study \\
\hline
\end{tabular}


increase the accuracy of these production measurements.

Since this study was conducted, other reports have shown that the concentration of viruses in a sample will decrease with time when stored with $2 \%$ formaldehyde or $0.5 \%$ glutaraldehyde at $4^{\circ} \mathrm{C}$ (Brussaard 2004, Wen et al. 2004). These reports did not include data for storage of viruses in $2 \%$ glutaraldehyde, the concentration used in this study, but a discussion of the possible effects of storage on the results presented in this study is warranted. The production rates of viruses would not be considerably affected by loss of viruses during storage because the samples for virus enumeration were all filtered on the same day, resulting in a similar decrease in virus concentration (if any) for all samples, which would not affect the calculated rates of increase in virus concentrations in the incubations. Any loss of viruses in stored samples would have the most direct effect on the concentrations of viruses reported in the depth profile, and thus also affect calculations of virus turnover times. However, an underestimation of virus concentrations by approximately 40 to $50 \%$ as a result of storage for $5 \mathrm{~d}$ (Wen et al. 2004) would mean that D-DNA within viruses was approximately $100 \%$ of the total D-DNA pool at Stn ALOHA. This result would be highly unlikely, especially since an average of $45 \%$ of the D-DNA pool was hydrolyzable by DNase, which does not hydrolyze DNA within viruses (Brum et al. 2004). Furthermore, a major factor in the decrease of enumerated bacteria in preserved samples is protease activity (Gundersen et al. 1996), which would presumably also affect viruses in preserved samples. The majority of ectoenzyme activity in aquatic environments is associated with microbial cells (Chróst 1990), which were removed from the virus enumeration samples in this study by $0.22 \mu \mathrm{m}$ filtration. Brussard (2004) and Wen et al. (2004) also conducted their studies of virus preservation with samples from coastal environments which would have higher concentrations of microbes, and therefore higher protease activity to reduce virus counts, than samples collected from an oligotrophic open-ocean environment such as Stn ALOHA. Finally, the concentrations of viruses in the depth profile of this study were slightly higher than the concentrations reported for Stn ALOHA by Culley \& Welschmeyer (2002), who also used $2 \%$ glutaraldehyde as a fixative but filtered their samples at sea with no stated storage time. It is therefore unlikely that the virus concentrations reported in this study were significantly affected by sample storage conditions, but further investigation into the effects of $2 \%$ glutaraldehyde fixation of virus samples in oligotrophic environments is needed to confirm this.

\section{CONCLUSIONS}

This research has shown that measurements of concentration, production and turnover of the individual components of the D-DNA pool greatly increase the understanding of the ecological roles of D-DNA in the marine environment. ehD-DNA was shown to be quickly cycled in this open-ocean gyre system, potentially supporting bacterial phosphorus and/or nucleotide demand, and viruses were shown to lyse a significant portion of the bacterial population at this site. These are important roles within the microbial loop that should be investigated further to understand how ehD-DNA is utilized by bacteria and to what extent viruses affect individual microbial population dynamics and recycling of DOM in the open ocean.

Acknowledgements. I thank the captain and crew of the RV 'Kilo Moana' for their assistance at sea. I acknowledge the support received from the Seagoing Technical Assistance Group and the technicians, students, and post-docs of the Hawaii Ocean Time-series program. I thank K. Selph for measuring bacterial concentrations, K. Björkman for her assistance at sea, and G. Steward for his assistance in viral genome fingerprinting. I especially thank D. Karl and G. Steward for their exceptional advice and critical reading of this manuscript. This work was supported by the NSF grant OCE 9617409 to D. Karl. This is SOEST contribution 6635 and USJGOFS contribution 1062.

\section{LITERATURE CITED}

Alonso MO, Rodriguez V, Rodriguez J, Borrego JJ (2000) Role of ciliates, flagellates and bacteriophages on the mortality of marine bacteria and on dissolved-DNA concentration in laboratory experimental systems. J Exp Mar Biol Ecol 244: 239-252

Ammerman JW, Azam F (1985) Bacterial 5'-nucleotidase in aquatic ecosystems: a novel mechanism for phosphorus regeneration. Science 227:1338-1340

Beebee TJC (1991) Analysis, purification and quantification of extracellular DNA from aquatic environments. Freshw Biol 25:525-532

Björkman KM, Karl DM (2003) Bioavailability of dissolved organic phosphorus in the euphotic zone at Station ALOHA, North Pacific Subtropical Gyre. Limnol Oceanogr 48:1049-1057

Boehme J, Frischer ME, Jiang SC, Kellogg CA, Pichard S, Rose JB, Steinway C, Paul JH (1993) Viruses, bacterioplankton, and phytoplankton in the southeastern Gulf of Mexico: distribution and contribution to oceanic DNA pools. Mar Ecol Prog Ser 97:1-10

Bratbak G, Thingstad F, Heldal M (1994) Viruses and the microbial loop. Microb Ecol 28:209-221

Brum JR, Steward GF, Karl DM (2004) A novel method for the measurement of dissolved deoxyribonucleic acid in seawater. Limnol Oceanogr Methods 2:248-255

Brussaard CPD (2004) Optimization of procedures for counting viruses by flow cytometry. Appl Environ Microbiol 70: 1506-1513

Chróst RJ (1990) Microbial ectoenzymes in aquatic environments. In: Overbeck J, Chróst RJ (eds) Aquatic microbial 
ecology: biochemical and molecular approaches. Springer-Verlag, New York, p 47-78

Culley AI, Welschmeyer NA (2002) The abundance, distribution, and correlation of viruses, phytoplankton, and prokaryotes along a Pacific Ocean transect. Limnol Oceanogr 47:1508-1513

DeFlaun MF, Paul JH, Davis D (1986) Simplified method for dissolved DNA determination in aquatic environments. Appl Environ Microbiol 52:654-659

DeFlaun MF, Paul JH, Jeffrey WH (1987) Distribution and molecular weight of dissolved DNA in subtropical estuarine and oceanic environments. Mar Ecol Prog Ser 38: 65-73

Finkel SE, Kolter R (2001) DNA as a nutrient: novel role for bacterial competence gene homologs. J Bacteriol 183: 6288-6293

Frischer ME, Thurmond JM, Paul JH (1990) Natural plasmid transformation in a high-frequency-of-transformation marine Vibrio strain. Appl Environ Microbiol 56: 3439-3444

Frischer ME, Stewart GJ, Paul JH (1994) Plasmid transfer to indigenous marine bacterial populations by natural transformation. FEMS Microbiol Ecol 15:127-136

Fuhrman J (1992) Bacterioplankton roles in cycling of organic matter: the microbial food web. In: Falkowski PG, Woodhead AD (eds) Primary productivity and biogeochemical cycles in the sea. Plenum Press, New York, p 361-383

Fuhrman JA (1999) Marine viruses and their biogeochemical and ecological effects. Nature 399:541-548

Fuhrman JA, Azam F (1982) Thymidine incorporation as a measure of heterotrophic bacterioplankton production in marine surface waters: evaluation and field results. Mar Biol 66:109-120

Fuhrman JA, Noble RT (1995) Viruses and protists cause similar bacterial mortality in coastal seawater. Limnol Oceanogr 40:1236-1242

Gundersen K, Bratbak G, Heldal M (1996) Factors influencing the loss of bacteria in preserved seawater samples. Mar Ecol Prog Ser 137:305-310

Ishii N, Kawabata Zi, Nakano Si, Min MG, Takata R (1998) Microbial interactions responsible for dissolved DNA production in a hypereutrophic pond. Hydrobiologia 380: $67-76$

Jeffrey WH, Paul JH, Stewart GJ (1990) Natural transformation of a marine Vibrio species by plasmid DNA. Microb Ecol 19:259-268

Jiang SC, Paul JH (1995) Viral contribution to dissolved DNA in the marine environment as determined by differential centrifugation and kingdom probing. Appl Environ Microbiol 61:317-325

Jones DR, Karl DM, Laws EA (1996) Growth rates and production of heterotrophic bacteria and phytoplankton in the North Pacific subtropical gyre. Deep-Sea Res I 43: $1567-1580$

Jørgensen NOG, Jacobsen CS (1996) Bacterial uptake and utilization of dissolved DNA. Aquat Microb Ecol 11: 263-270

Jørgensen NOG, Kroer N, Coffin RB, Yang X-H, Lee C (1993) Dissolved free amino acids, combined amino acids, and DNA as sources of carbon and nitrogen to marine bacteria. Mar Ecol Prog Ser 98:135-148

Jørgensen NOG, Kroer N, Coffin RB (1994) Utilization of dissolved nitrogen by heterotrophic bacterioplankton: effect of substrate C/N ratio. Appl Environ Microbiol 60: 4124-4133

Karl DM, Bailiff MD (1989) The measurement and distribution of dissolved nucleic acids in aquatic environments. Limnol
Oceanogr 34:543-558

Karl DM, Bidigare RR, Letelier RM (2001a) Long-term changes in plankton community structure and productivity in the subtropical North Pacific Ocean: the domain shift hypothesis. Deep-Sea Res II 48:1449-1470

Karl DM, Björkman KM, Dore JE, Fujieki L, Hebel DV, Houlihan T, Letelier RM, Tupas LM (2001b) Ecological nitrogen-to-phosphorus stoichiometry at station ALOHA. Deep-Sea Res II 48:1529-1566

Kawabata Zi, Ishii N, Nasu M, Min MG (1998) Dissolved DNA produced through a prey - predator relationship in a species-defined aquatic microcosm. Hydrobiologia 385:71-76

Maruyama A, Oda M, Higashihara T (1993) Abundance of virus-sized non-DNase-digestible DNA (coated DNA) in eutrophic seawater. Appl Environ Microbiol 59:712-717

Matsui K, Honjo M, Kawabata Zi (2001) Estimation of the fate of dissolved DNA in thermally stratified lake water from the stability of exogenous plasmid DNA. Aquat Microb Ecol 26:95-102

Monger BC, Landry MR (1993) Flow cytometric analysis of marine bacteria with Hoechst 33342. Appl Environ Microbiol 59:905-911

Noble RT, Fuhrman JA (1998) Use of SYBR Green I for rapid epifluorescence counts of marine viruses and bacteria. Aquat Microb Ecol 14:113-118

Paul JH, David AW (1989) Production of extracellular nucleic acids by genetically altered bacteria in aquatic-environment microcosms. Appl Environ Microbiol 55:1865-1869

Paul JH, Jeffrey WH, DeFlaun MF (1987) Dynamics of extracellular DNA in the marine environment. Appl Environ Microbiol 53:170-179

Paul JH, DeFlaun MF, Jeffrey WH (1988) Mechanisms of DNA utilization by estuarine microbial populations. Appl Environ Microbiol 54:1682-1688

Paul JH, Jeffrey WH, Cannon JP (1990) Production of dissolved DNA, RNA, and protein by microbial populations in a Florida reservoir. Appl Environ Microbiol 56: $2957-2962$

Paul JH, Jiang SC, Rose JB (1991) Concentration of viruses and dissolved DNA from aquatic environments by vortex flow filtration. Appl Environ Microbiol 57:2197-2204

Siuda W, Chróst RJ (2000) Concentration and susceptibility of dissolved DNA for enzyme degradation in lake water some methodological remarks. Aquat Microb Ecol 21: 195-201

Siuda W, Güde H (1996) Evaluation of dissolved DNA and nucleotides as potential sources of phosphorus for plankton organisms in Lake Constance. Ergeb Limnol 48: 155-162

Siuda W, Chróst RJ, Güde H (1998) Distribution and origin of dissolved DNA in lakes of different trophic states. Aquat Microb Ecol 15:89-96

Skoog DA, West DM, Holler FJ, Crouch SR (2000) Analytical chemistry: an introduction. Saunders College Publishing, Fort Worth, TX

Steward GF (2001) Fingerprinting viral assemblages by pulsed field gel electrophoresis (PFGE). In: Paul JH (ed), Methods in microbiology. Academic Press, New York, p 85-103

Steward GF, Smith DC, Azam F (1996) Abundance and production of bacteria and viruses in the Bering and Chukchi Seas. Mar Ecol Prog Ser 131:287-300

Steward GF, Montiel JL, Azam F (2000) Genome size distributions indicate variability and similarities among marine viral assemblages from diverse environments. Limnol Oceanogr 45:1697-1706

Turk V, Rehnstam AS, Lundberg E, Hagström ^̊ (1992) Release of bacterial DNA by marine nanoflagellates, an 
intermediate step in phosphorus regeneration. Appl Environ Microbiol 58:3744-3750

Weinbauer MG, Suttle CA (1999) Lysogeny and prophage induction in coastal and offshore bacterial communities. Aquat Microb Ecol 18:217-225

Weinbauer MG, Fuks D, Peduzzi P (1993) Distribution of viruses and dissolved DNA along a coastal trophic gradient in the Northern Adriatic Sea. Appl Environ Microbiol 59:4074-4082

Weinbauer MG, Fuks D, Puskaric S, Peduzzi P (1995) Diel, seasonal, and depth-related variability of viruses and dissolved DNA in the Northern Adriatic Sea. Microb Ecol

Editorial responsibility: Jed Fuhrman,

Los Angeles, California, USA
$30: 25-41$

Wen K, Ortmann AC, Suttle CA (2004) Accurate estimation of viral abundance by epifluorescence microscopy. Appl Environ Microbiol 70:3862-3867

Wilhelm SW, Suttle CA (1999) Viruses and nutrient cycles in the sea. BioScience 49:781-788

Wilhelm SW, Brigden SM, Suttle CA (2002) A dilution technique for the direct measurement of viral production: a comparison in stratified and tidally mixed coastal waters. Microb Ecol 43:168-173

Wommack KE, Colwell RR (2000) Virioplankton: viruses in aquatic ecosystems. Microbiol Mol Biol Rev 64:69-114

Submitted: July 18, 2004; Accepted: July 11, 2005

Proofs received from author(s): October 25, 2005 